ISSN 0258-7122

Bangladesh J. Agril. Res. 36(1) : 129-141, March 2011

\title{
FARMERS' EFFICIENCY ENHANCEMENT THROUGH INPUT MANAGEMENT: THE ISSUE OF USG APPLICATION IN MODERN RICE
}

\author{
M. SHAHE ALAM ${ }^{1}$, M. SAIFUL ISLAM ${ }^{2}$ AND M. A. ISLAM ${ }^{3}$
}

\begin{abstract}
A socio-economic study was carried out in two rice production environments (Gazipur and Tangail) to assess the comparative advantages of using urea super granule (USG) over prilled urea (PU) in modern rice production and to examine the differences in producers' technical efficiency between USG user and nonuser in crop management. Stochastic frontier production model was employed to examine the farm specific technical efficiency difference in crop management between USG and PU users in the study areas. Analysis revealed that comparatively low amount (36\%) of urea was needed in modern boro rice production using USG instead of PU. Nearly 366 \% more labour was needed in the USG using plots compared to that of PU user plots, while weeding cost was a bit lower in USG using plots. Analysis also indicated that the sample farmers were able to achieve additional yield of 0.87 t/ha by using USG and this yield gain further resulted to additional benefit of Tk. 11506/ha. For the resource poor rice farms, this benefit is considered to be substantive. Farmers' contact with the technology disseminators, training on rice production and the use of USG (instead of PU) were the important factors of increasing rice farmers' technical efficiency in crop management and productivity enhancement as well. According to the farmers' opinion, there were several constraints in using USG and out of those, requirement of more labour and non availability of USG in proper time were the dominant ones.
\end{abstract}

Keywords: Urea super granule, prilled urea, flood-prone ecosystem, technical efficiency, productivity.

\section{Introduction}

Rapid advancement in seed-fertilizer technology in the rice sector of Bangladesh has made notable breakthrough in the adoption of modern rice varieties at farm level during the last three decades. The overall adoption of modern rice varieties in the country has already expanded nearly to $74 \%$, while in the Boro season, the coverage of modern varieties has very impressively reached about $96 \%$ contributing to nearly $57 \%$ of the total rice production. (BBS, 2008). It is well recognized that modem rice varieties (MVs) are always responsive to balanced application of fertilizer coupled with irrigation water.

${ }^{1}$ Chief Scientific Officer, ${ }^{2}$ Senior Scientific Officer and ${ }^{3}$ Scientific Officer, Agricultural Economics Division, Bangladesh Rice Research Institute (BRRI), Gazipur 1701, Bangladesh. 
Nitrogen is one of the most essential elements for the growth of rice plant. Proper management of nitrogen is obligatory to improve crop growth and grain yield. In most cases, farmers use imbalance dose of nitrogen $(\mathrm{N})$ fertilizer which causes higher insects/disease infestation resulting to lower yield. Generally farmers are accustomed to use $\mathrm{N}$ fertilizer in the form of prilled urea (PU) which is very easy to apply though rice plant can receive only 25 to $30 \%$ of applied fertilizer (BRRI, 2007). To reduce nitrogen loss, application of urea super granule (USG) is strongly considered to be an important alternative that increases the efficiency of $\mathrm{N}$ about 20 to $25 \%$ and also increases the yield by 15 to $20 \%$ (BRRI, 2008). In the recent past, price of urea fertilizer has increased in the international markets. Consequently, there has been severe upward shift in fertilizer price in Bangladesh and accordingly the government had to provide huge amount of subsidies on fertilizer every year. Prices of other fertilizers (like TSP and MP) are also high. So, government needs to provide more subsidy on those fertilizers to maintain soil health and enhancing productivity. In the year 2008, government has increased the price of urea to control the excess use of urea and to reduce subsidy. Government has been trying to encourage farmers in using USG instead of prilled urea (PU) in rice production in order to reduce $\mathrm{N}$ loss that would in turn enhance productivity (Rahman et al; 2004). Virtually, there has been very scanty/minimum research works done so far in digging into farmers' interaction and efficiency differences between the USG and PU users at the end-users level. Taking into consideration of all these issues, the present study was undertaken.

\section{Specific objectives}

The specific objectives of the study were formulated as:

- To know the comparative advantages of using USG over prilled urea in modern rice production;

- To examine the differences in rice farmers' technical efficiency in crop management between USG user and non-user;

- To identify the problems in using USG in rice production at farmers' field, and

- To derive policy implications from the above.

\section{Methodology}

The study was conducted during Boro season of 2008. Two districts, namely Tangail and Gazipur were selected purposively to represent two different production environments. i.e. Tangail as the flood prone and Gazipur as flood free production environment. Two upazila under each district were also selected purposively. One village under each upazila (where intensive USG using farms 
were available) was also selected purposively in consultation with the local Agriculture Extension Department workers. From a comprehensive list of Boro growing farmers in the village, 15 USG users and 15 non-users from each village were selected randomly. Therefore, a total of 120 (i,e. $15 * 4 * 2$ ) sample farms were taken under this study. Necessary data were collected using pre-designed questionnaire through interviewing the sample farmers. Both descriptive and inferential statistics were employed in analyzing the data. In estimating the farm specific technical efficiency, the most widely used stochastic frontier production function model was used (Coelli, 1994).

\subsection{Conceptual background of technical efficiency}

Efficiency is a very important factor of productivity growth, especially in developing agricultural economies, such as Bangladesh where farmers' resources are meagre. Production efficiency relates outputs with inputs. It can be measured in terms of inputs required to produce a given level of output, or it can be assessed from the total output produced from a given level of input. Output is a result not only of the quantity of inputs used but also of the efficiency in the use of these inputs. A firm producing on a certain production function may increase production by improving the efficiency of use of the inputs without increasing the level of inputs; thereby shifting the production function upwards. A production process is said to be efficient if there is no alternative process which produces more output with the same inputs or produces the same output with less inputs. Technical efficiency refers to the attainment of the maximum possible output level for any combination of inputs employed in production. It is thus defined as the ratio of actual output of a firm to the maximum possible output with the given set of inputs. Technical efficiency, therefore, reveals possibilities for increasing output without increasing cost or without re-arranging input combination. A firm is, therefore, technically in-efficient if it fails to produce the maximum level of output given a set of inputs (Alam, 2006).

For the sake of simplicity, let us consider, a firm employing two factors of production to produce a singe product under the conditions of constant returns to scale. Farrel (1957) took supposition that the efficient production function is known, i.e. the output that a perfectly efficient firm could obtain any given combination of inputs. The assumption of constant returns permits all the relevant information to be presented in a simple 'isoquant' diagram (Fig. 1). The point $P$ represents the inputs of the two factors, per unit of output that the firm is observed to use. The isoquant SS' represents the various combinations of the two factors that a perfectly efficient firm might use to produce unit output.

The point $\mathrm{Q}$ represents an efficient firm using the two factors in the same ratio as $\mathrm{P}$. It can be observed that the firm produces the same output as $\mathrm{P}$ using only a fraction OQ/OP as much of each factor. It could also be thought of as 
producing $\mathrm{OP} / \mathrm{OQ}$ times as much output from the same inputs. It, therefore, seems logical to define OQ/OP as the technical efficiency of the firm P. This ratio has the properties that a measure of efficiency obviously needed. In fact, it takes the value unity (or 100 percent) for a perfectly efficient firm, and becomes indefinitely small if the amounts of input per unit output become indefinitely large. Moreover, as long as SS' has a negative slope, an increase in the input per unit of output of one factor will, ceteris puribus, imply lower technical efficiency. If a firm uses quantities of inputs, defined by the point $\mathrm{P}$, to produce a unit of output, the technical inefficiency of that firm could be represented by the distance QP, which is the amount by which all inputs could be proportionally reduced without a reduction in output.

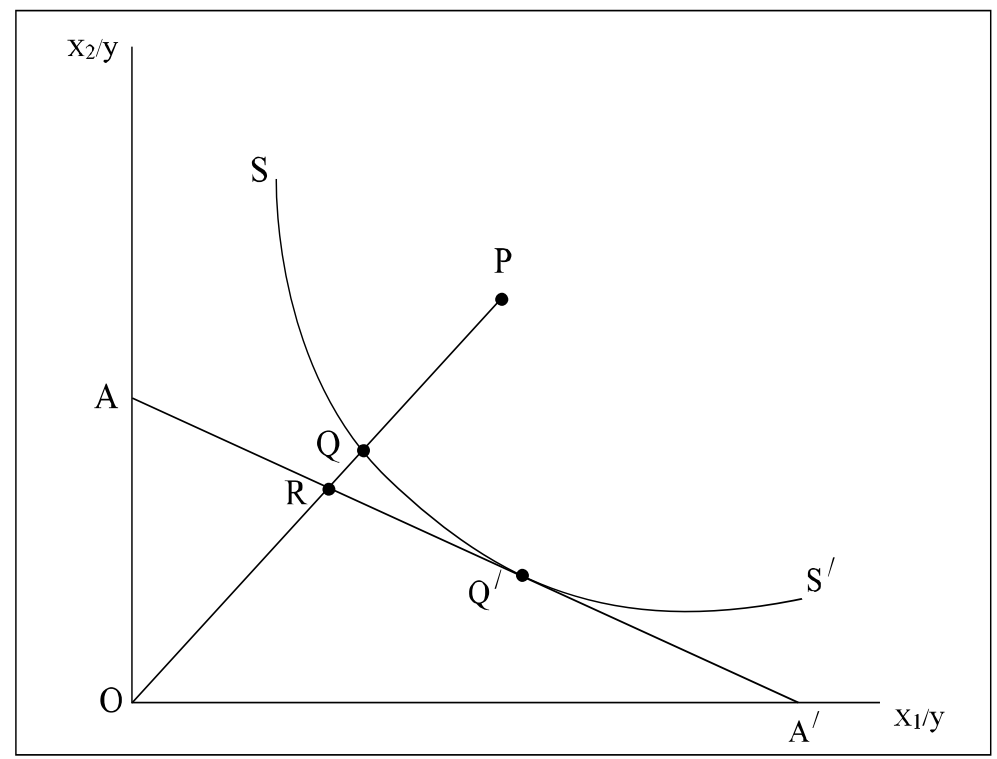

Fig. 1: Model showing technical efficiency in relative input-output space.

The frontier approach has been widely used to identify technical inefficiency and its causes in agricultural production process (Battest and Coelli,1995). Using a parametric production function (as in Bravo-Ureta and Evenson, 1994) of the following form, technical efficiency could be examined:

$\mathrm{Y}_{\mathrm{i}}=\mathrm{X}_{\mathrm{i}} \beta_{\mathrm{i}}+\varepsilon_{\mathrm{i}}$

Where $Y_{i}=$ rice yield, $X_{i}=$ is a $\left(K_{i} \times 1\right)$ matrix of inputs, $\beta_{i}=$ is a $\left(K_{i} \times 1\right)$ matrix of parameters associated with $X_{i}, \varepsilon_{i}=$ error terms, and $i=$ is the $i^{\text {th }}$ observation. The 'stochastic frontier (also called 'composed error') model, introduced by Aigner, Lovell and Schmidt (1977) and Meeusen and van den Broeck (1977), postulates that the error term $\varepsilon_{1}$ is made up of two independent components:

$\varepsilon_{\mathrm{i}}=\mathrm{V}_{\mathrm{i}}-\mathrm{U}_{\mathrm{i}}$ 
The error component $\mathrm{V}_{1}$ represent the symmetrical disturbance that captures random errors. erroneous data etc, and is assumed to be identically and independently distributed as $\mathrm{N}\left(\mathrm{O}, \sigma_{\mathrm{v}}{ }^{2}\right)$. The error component $\mathrm{u}_{1}$ is non-negative random variables, associated with technical inefficiency in production assumed to be independently and identically distributed and truncations (at zero) of the normal distribution with mean and variance $\mathrm{N}\left(0, \sigma_{\mathrm{u}}^{2}\right)$, such that, the distribution of $\mathrm{u}_{\mathrm{i}}$ is half normal. $\left|\mathrm{u}_{\mathrm{i}}\right|>0$ reflects the technical efficiency relative to the frontier. $\left|u_{i}\right| \leq 0$ for a firm whose production lies on the frontier and $\left|u_{i}\right| \leq$ 0 for a firm whose production lies below the frontier. According to Battese and Coelli (1995), technical inefficiency effects are defined by:

$\mathrm{U}_{\mathrm{i}}=\mathrm{Z}_{\mathrm{i}} \delta+\mathrm{W}_{\mathrm{i}}$

$Z_{i}$ is a vector of explanatory variables associated with the technical inefficiency effects.

$\delta$ is a vector of unknown parameters to be estimated. $\mathrm{W}_{\mathrm{i}}$ is unobservable random variables. which are assumed to be identically distributed, obtained by truncation of the normal distribution with mean zero and unknown variance $\sigma^{2}$, such that $U_{i}$ is non-negative.

Stochastic frontier production functions can be estimated using either the maximum likelihood method or using a variant of the COLS (corrected ordinary least squares) method suggested by Richmond (1974). According to Battese and Corra (1977), the variance ratio parameter $\gamma$ which relates the variability of $u_{i}$ to total variability $\left(\sigma^{2}\right)$ can be calculated in the following manner;

$\gamma=\left(\sigma_{\mathrm{u}}^{2} / \sigma^{2}\right)$

So that $0 \leq \gamma \leq 1$

If the value of $\gamma$ equals zero the difference between farmers yield and the efficient yield is entirely due to statistical noise. On the other hand, a value of one would indicate the difference attributed to the farmers' less than efficient use of technology i.e. technical inefficiency (Coelli, 1995).

\section{Results and Discussion}

\subsection{Level of input use in USG and PU using plots}

In USG applying plots comparatively low amount of seed and urea was used. But slightly higher amount of other fertilizers were applied in USG using plots. In Kalihati comparatively high amount of USG was used $(219 \mathrm{~kg} / \mathrm{ha})$ and in Gopalpur, highest amount of PU (279 kg/ha) was used. About II imandays were needed to apply USG and in Kalihati this number was only 6 which means that the labour of Kalihati was more efficient in applying USG. In Kalihati, labour 
requirement for weeding was also lower implying that weed infestation was also lower (Table 1).

Table 1. Comparative input use level in USG and PU using plots in different study locations.

\begin{tabular}{|c|c|c|c|c|c|c|c|c|c|c|}
\hline \multirow[b]{2}{*}{ Items } & \multicolumn{2}{|c|}{ Kaligong } & \multicolumn{2}{|c|}{ Kapasia } & \multicolumn{2}{|c|}{ Kalihati } & \multicolumn{2}{|c|}{ Gopalpur } & \multicolumn{2}{|c|}{ All locations } \\
\hline & $\begin{array}{l}\text { USG } \\
\text { plot }\end{array}$ & $\begin{array}{l}\text { PU } \\
\text { plot }\end{array}$ & $\begin{array}{l}\text { USG } \\
\text { plot }\end{array}$ & $\begin{array}{l}\text { PU } \\
\text { plot }\end{array}$ & $\begin{array}{l}\text { USG } \\
\text { plot }\end{array}$ & $\begin{array}{l}\text { PU } \\
\text { plot }\end{array}$ & $\begin{array}{l}\text { USG } \\
\text { plot }\end{array}$ & $\begin{array}{l}\text { PU } \\
\text { plot }\end{array}$ & $\begin{array}{l}\text { USG } \\
\text { plot }\end{array}$ & $\begin{array}{l}\text { PU } \\
\text { plot }\end{array}$ \\
\hline Seed (kg/ha) & 41 & 50 & 30 & 31 & 38 & 47 & 41 & 48 & 37 & 44 \\
\hline $\begin{array}{l}\text { USG/PU } \\
(\mathrm{kg} / \mathrm{ha})\end{array}$ & 161 & $\begin{array}{c}216 \\
(34.16)\end{array}$ & 147 & $\begin{array}{c}179 \\
(21.77)\end{array}$ & 219 & $\begin{array}{c}245 \\
(11.87)\end{array}$ & 150 & $\begin{array}{l}279 \\
(86)\end{array}$ & 169 & $\begin{array}{c}230 \\
(36.09)\end{array}$ \\
\hline TSP (kg/ha) & 94 & 79 & 90 & 90 & 113 & 105 & 118 & 108 & 104 & 96 \\
\hline MP(kg/ha) & 45 & 31 & 85 & 85 & 71 & 54 & 80 & 96 & 70 & 67 \\
\hline $\begin{array}{l}\text { Gypsum } \\
\text { (kg/ha) }\end{array}$ & 34 & 26 & 72 & 72 & 58 & 47 & 44 & 25 & 52 & 42 \\
\hline $\begin{array}{l}\text { Zinc } \\
\text { (kg/ha) }\end{array}$ & 3.96 & 1.73 & 6.82 & 6.82 & 6.12 & 2.99 & 5.75 & $1.66 \mathrm{I}$ & 5.66 & 3.33 \\
\hline $\begin{array}{l}\text { Cowdung } \\
\text { (Md/ha) }\end{array}$ & 115 & 120 & 140 & 150 & 0 & 34 & 0 & 47 & 64 & 88 \\
\hline $\begin{array}{l}\text { Lab. for urea } \\
\text { appl.(No./ha) }\end{array}$ & 12 & 2.25 & 14 & 2.25 & 6 & 2.25 & 10 & 2.25 & 10.5 & $\begin{array}{c}2.25 \\
(366)\end{array}$ \\
\hline
\end{tabular}

Figures in parentheses indicate percent increases

Source: Field survey, 2008

\subsection{Differences in cost structure}

Analysis revealed that seed cost was higher in the plots with PU since farmers used higher amount of seed. Fertilizer cost was higher (Tk.9134/ha) in USG plot, compared to that of PU using plots. Cost for urea fertilizer in PU plot was about $17.6 \%$ higher than that of USG using plots. In Kalihati and Gopalpur, weeding cost per hectare in USG plot was Tk. 5154 and Tk. 5864, respectively, and in PU plot, it was Tk. 6777 and Tk. 7165, respectively, which means that comparatively low weed infestation was found in Kalihati and Gopalpur in USG using plots. The USG users in Gopalpur did not use any insecticides. Irrigation cost was much higher both in Kalihati and Gopalpur as one forth crop was given for irrigation. In Kaligonj, irrigation charge was paid in cash and as such the amount was the lowest (8000 Tk./ha). Total cost of production in USG plot was Tk. 40288/ha and it was Tk. 37837/ha in PU plot (Table 2). 
Table 2. Comparative cost structure (Tk.Iha) between USG and PU using plots, Boro, 2008.

\begin{tabular}{l|c|c|c|c|c|c|c|c}
\hline \multirow{2}{*}{ Cost items } & \multicolumn{2}{|c|}{ Kaligonj } & \multicolumn{2}{c|}{ Kapasia } & \multicolumn{2}{c}{ Kalihati } & \multicolumn{2}{c}{ Gopalpur } \\
\cline { 2 - 9 } & $\begin{array}{l}\text { USC } \\
\text { plot }\end{array}$ & $\begin{array}{c}\text { PU } \\
\text { plot }\end{array}$ & $\begin{array}{c}\text { USC } \\
\text { plot }\end{array}$ & $\begin{array}{c}\text { PU } \\
\text { plot }\end{array}$ & $\begin{array}{c}\text { USC } \\
\text { plot }\end{array}$ & $\begin{array}{c}\text { PU } \\
\text { plot }\end{array}$ & $\begin{array}{c}\text { USC } \\
\text { plot }\end{array}$ & PU plot \\
\hline Seed & 1230 & 1506 & 897 & 929 & 1145 & 1406 & 1217 & 1426 \\
Urea & 1208 & 1316 & 1029 & 1162 & 1535 & 1468 & 1021 & 1692 \\
TSP+MP & 4600 & 3735 & 4832 & 4832 & 6802 & 5120 & 7197 & 7329 \\
Gypsum & 240 & 207 & 574 & 574 & 362 & 325 & 266 & 188 \\
Zinc & 423 & 221 & 614 & 61314 & 367 & 156 & 363 & 137 \\
Cowdung & 2300 & 2400 & 2800 & 3000 & 0 & 674 & 0 & 702 \\
Lab. cost for & 2109 & 382 & 2380 & 382 & 851 & 315 & 1470 & 337 \\
urea appl. & & & & & & & & \\
insecticide & 1083 & 1400 & 2303 & 2169 & 370 & 609 & 0 & 447 \\
Weeding cost: & 9309 & 9707 & 8743 & 8562 & 5154 & 6777 & 5864 & 7165 \\
Irrigation & 7892 & 8295 & 11518 & 11518 & 31480 & 24760 & 29600 & 27400 \\
Total cost & 30395 & 29169 & 35691 & 33743 & 48068 & 41609 & 46999 & 46825 \\
\hline
\end{tabular}

Figure in parentheses indicate percent

\subsection{Comparative advantages of USG use over PU}

Economic benefit in USG application instead of PU was also assessed and the result is presented in Table 3. It appears that on average, $60 \mathrm{~kg}$ of urea could be saved by using USG. Highest amount of urea was saved in Gopalpur as the farmers of Gopalpur used comparatively high amount of urea (279 kg/ha). Using USG, no significant amount of money could be saved since price of USG was higher and additional labor cost for USG application was Tk. 1350/ha. The main benefit as gained was additional yield of $0.87 \mathrm{t} / \mathrm{ha}$ (13.33\% higher) and the additional benefit was Tk. 11506/ha. Maximum yield gain was observed in Kalihati (l.68 t/ha) and additional benefit achieved from USG using plots was Tk. 20421/ha. 
Table 3. Comparative advantages of USG use over PU application.

\begin{tabular}{|c|c|c|c|c|c|}
\hline Items & Kaligonj & Kapasia & Kalihati & Gopalpur & $\begin{array}{c}\text { All } \\
\text { locations }\end{array}$ \\
\hline Urea saved (kg/ha) & 55 & 32 & 25 & 129 & 60 \\
\hline $\begin{array}{l}\text { Aditional labor for USG } \\
\text { application (No.) }\end{array}$ & 10 & 12 & 4 & 7.55 & 8.38 \\
\hline Yield of USG plot (t/ha) & $\begin{array}{c}6.68 \\
(9.33)\end{array}$ & $\begin{array}{c}7.58 \\
(9.70)\end{array}$ & $\begin{array}{c}7.87 \\
(27.14)\end{array}$ & $\begin{array}{c}7.40 \\
(8.03)\end{array}$ & $\begin{array}{c}7.39 \\
(13.33)\end{array}$ \\
\hline Yield of PU plot (t/ha) & 6.11 & 6.91 & 6.19 & 6.85 & 6.52 \\
\hline $\begin{array}{l}\text { Additional yield from USG } \\
\text { plot (t/ha) }\end{array}$ & 0.57 & 0.67 & 1.68 & 0.55 & 0.87 \\
\hline $\begin{array}{l}\text { Money saved from urea } \\
(\mathrm{Tk} / \mathrm{ha})\end{array}$ & 108 & 133 & -67 & 672 & 211 \\
\hline $\begin{array}{l}\text { Additional labour cost for } \\
\text { USG (Tk/ha) }\end{array}$ & 1727 & 1997 & 536 & 1133 & 1348 \\
\hline $\begin{array}{l}\text { Additional benefit from } \\
\text { USG plot (Tk./ha) }\end{array}$ & 8037 & 8940 & 20421 & 8627 & 1727 \\
\hline
\end{tabular}

Note: Figures in the parentheses indicate percent increase

\subsection{Partial budget analysis}

Partial budget analysis was done to assess the break down of economic advantage of USG over PU application. However, in exercising the partial budgeting technique, analysis indicated that rice farmers could earn additional benefit of Tk. 9059/ha by USG application instead of using the PU (Table 4).

Table 4 Partial budgeting for USG application versus PU.

\begin{tabular}{|c|c|c|c|}
\hline \multirow{2}{*}{ Items } & Debit (Tk./ha) & \multirow{2}{*}{ Items } & Credit (Tk/ha) \\
\hline & USG method & & PU method \\
\hline $\begin{array}{l}\text { 1. Additional cost for } \\
\text { application of USG }\end{array}$ & 40288 & $\begin{array}{l}\text { 2. Cost saved for not } \\
\text { applying PU }\end{array}$ & 37837 \\
\hline $\begin{array}{l}\text { 3. Revenue foregone } \\
\text { for not applying } \\
\text { PU. }\end{array}$ & 86260 & $\begin{array}{l}\text { 4. Revenue earned } \\
\text { for undertaking } \\
\text { USG application }\end{array}$ & 97770 \\
\hline Profit/Loss & +9059 & & \\
\hline Total & $1,35,607$ & & $1,35,607$ \\
\hline
\end{tabular}




\subsection{Technical efficiency estimation}

\section{Empirical model}

The following Cobb-Douglas stochastic production function (for the sample farmers) was specified:

$\operatorname{In} Y_{i}=\beta_{0}+\beta_{1} \ln X_{1},+\beta_{2} \ln X_{2}+\beta_{3} \ln X_{3}+\beta_{4} \ln X_{4}+\beta_{5} \ln X_{5}+\beta_{6} \ln X_{6}+\beta_{7} \ln X_{7}+V_{i}-U_{i}$.

where, $I n=$ Natural logarithm;

$\mathrm{Y}_{\mathrm{i}}=$ Yield of paddy for the plot $(\mathrm{kg} / \mathrm{ha})$;

$X_{i}=$ Urea $(\mathrm{kg} / \mathrm{ha})$;

$\mathrm{X}_{2}=\mathrm{TSP}(\mathrm{kg} / \mathrm{ha})$;

$\mathrm{X}_{3}=\mathrm{MP}(\mathrm{kg} / \mathrm{ha})$

$\mathrm{X}_{4}=\mathrm{Gypsum}(\mathrm{kg} / \mathrm{ha})$;

$\mathrm{X}_{5}=$ Zinc $(\mathrm{kg} / \mathrm{ha})$

$\mathrm{X}_{6}=$ Cowdung $(\mathrm{md} / \mathrm{ha})$

$\mathrm{X}_{7}=$ Labour cost $(\mathrm{Tk} . / \mathrm{ha})$

$\beta_{0}=$ Constant

$\beta_{\mathrm{i}}=$ Co-efficient of parameters

$\mathrm{V}_{\mathrm{i}}$ is an independently and identically distributed random error and $\mathrm{U}_{\mathrm{i}}$ is a nonnegative variable, associated with technical inefficiency in production;

$i=1,2, \ldots ., 120$

The technical inefficiency effects, $U_{i}$ was defined as: (Coelli,1995)

$U_{i}=\delta_{0}+\delta_{j} Z_{i}$,

Where, $Z_{1}=$ Age of ith farmer

$Z_{2}=$ Education (Years of Schooling);

$Z_{3}=$ Farming experience (Years);

$\mathrm{Z}_{4}=$ Extension contact (no. of contact per month)

$\mathrm{Z}_{5}=$ Tenancy dummy using value 1 if the farmer is an owner operator, 0 otherwise

$\mathrm{Z}_{6}=$ No. of agricultural labour in the family

$\mathrm{Z}_{7}=$ Training dummy showing value 1 if the farmer is trained, 0 otherwise

$\mathrm{Z}_{8}=$ USG user dummy showing value 1 if the farmer is USG user, 0 otherwise

$\delta_{0}=$ Constant;

$\delta_{\mathrm{i}}=$ unknown parameters to be estimated;

$i=1,2, \ldots \ldots ., 120$. 
The maximum likelihood estimates of the parameters for the Cobb-Douglas frontier production model (estimated using frontier 4.1 version) is presented in Table 5. Among different physical inputs/variables, application of nitrogen (Urea) and zinc had positive and significant contribution to enhance yield of modem Boro rice at the farmers' field under the sample areas. Use of more human labour also showed positive influence on the yield of MV Boro. Among the inefficiency factors, contact with technology disseminators, training dummy and USG user dummy were significant at $5 \%$ and $1 \%$ level, respectively, and their sign were negative indicating that if the farmers increase contact with technology disseminators, their inefficiency in crop management will decrease; in other words, the level of efficiency will increase. If the farmers could receive training, their inefficiency will also decrease meaning that their efficiency will increase significantly. This findings were in consonance with that of an earlier study (Islam et al., 2007). Similarly, the use of USG will decrease inefficiency indicating that the efficiency will increase. However, the overall efficiency was 81 percent. There is scope for increasing the efficiency by taking different measures.

Table 5. Maximum likelihood estimates of stochastic Cobb-Douglas production frontier for USG and PU users in the study areas.

\begin{tabular}{lccc}
\hline Name of variables & Parameters & Coefficient & t-ratio \\
\hline Constant & $\beta_{0}$ & 7.9009 & 2.046 \\
Ln Urea (kg/ha) & $\beta_{1}$ & $0.0995 * *$ & 2.046 \\
Ln TSP (kg/ha) & $\beta_{2}$ & 0.01244 & 0.599 \\
LnMP(kg/ha) & $\beta_{3}$ & 0.01436 & 0.901 \\
Ln Gypsum (kg/ha) & $\beta_{4}$ & 0.00502 & 0.563 \\
Ln Zinc (kg/ha) & $\beta_{5}$ & $0.02345^{*}$ & 1.897 \\
Ln Cowdung (kg/ha) & $\beta_{6}$ & -0.00105 & -0.137 \\
Ln Labour cost (Tk./ha) & $\beta_{7}$ & 0.04622 & 0.505 \\
Log-likelihood value & & 52.57 & \\
Mean Technical Efficiency & & $\mathbf{8 1 . 0 1}$ & \\
Variance Parameter: & & & \\
Sigma squared & $\sigma^{2}$ & 0.0203 & 5.613 \\
Gamma & $\gamma$ & 0.2228 & 0.243 \\
Inefficiency Function: & & & \\
Constant & $\delta_{0}$ & 0.1436 & 0.672 \\
Age & $\delta_{1}$ & 0.00129 & 0.651 \\
Education (Year of Schooling) & $\delta_{2}$ & -0.0008 & -0.156 \\
Farming Experience (Years) & $\delta_{3}$ & -0.0023 & - I .628 \\
Contact with technology disseminators & $\delta_{4}$ & $0.0016^{* *}$ & -2.891 \\
Ownership dummy & $\delta_{5}$ & 0.0675 & 1.097 \\
Number of family labour & $\delta_{6}$ & 0.0159 & 1.027 \\
Training dummy & $\delta_{7}$ & $0.0956^{* *}$ & -2.125 \\
USG user dummy & $\delta_{8}$ & $0.1573^{* * *}$ & -3.278 \\
\hline
\end{tabular}

***, *, * = Significant at $1 \%, 5 \%$ and $10 \%$ level of probability. 


\subsection{Differences of technical efficiency between USC users and non-users}

Analysis revealed that technical efficiency of USG users' plot was higher than that of PU users' plot. In USG using plot, average technical efficiency was nearly 90 percent and nearly 60 percent farms attained above average level of efficiency. On the other hand, in PU using plots, average efficiency was about 84 percent and about 45 percent farms attained above average level of efficiency (Table 6).

Table 6. Technical efficiency differences for the farms using USG and PU in MV boro production.

\begin{tabular}{l|c|c}
\hline \multicolumn{1}{c|}{ Items } & $\begin{array}{c}\text { USG user } \\
\text { farms }\end{array}$ & $\begin{array}{c}\text { PU user } \\
\text { farms }\end{array}$ \\
\hline Below 50 \% efficiency & 0 & 2.13 \\
Below average efficiency (\% farm) & 41.18 & 44.68 \\
Above average efficiency (\% farm) & 58.82 & 53.19 \\
Average T.E. level (\% farm) & 89.23 & 83.48 \\
\hline
\end{tabular}

\subsection{Farmers' perceptions on USG use in rice production}

Farmers' assessment on USG use was also evaluated. More than $90 \%$ farmers opined that the practice of USG application would save urea substantially (Table 7). Moreover, higher yield could be obtained by using USG (instead of PU) and this was opined by $76 \%$ farmers. However, majority of the sample farmers also agreed to the proposition that weed infestation was also lower in the plot of USG.

Table 7: Farmers' perceptions on the use of USG instead of PU in rice cultivation.

\begin{tabular}{l|c|c|c|c|c}
\hline \multirow{2}{*}{\multicolumn{1}{c}{ Advantages }} & \multicolumn{5}{c}{ \% farms opined } \\
\cline { 2 - 6 } & Kaligonj & Kapasia & Kalihati & Gopalpur & All locations \\
\hline Required less urea & 80 & 87 & 100 & 100 & 92 \\
Higher yield & 73 & 53 & 100 & 80 & 76 \\
Apply only one time & 67 & 87 & 47 & 27 & 57 \\
Less weed infestation & 27 & 33 & 80 & - & 35 \\
\hline
\end{tabular}

\subsection{Problems of USG use at farm level}

Farm level problems of using urea super granule were also evaluated and the analysis is presented in Table 8. In most of the study areas, sample farmers stated that the use of USG required more labour compared to that needed for PU. On the other hand, skilled labour is required for proper application of USG and this was stated by nearly $50 \%$ of the sample farms. 
Table 8: Stated problems of using USG at the farm level: 2008.

\begin{tabular}{l|c|c|c|c|c}
\hline \multirow{2}{*}{\multicolumn{1}{c}{ Problems }} & \multicolumn{5}{c}{ Locations / \% farmers opined } \\
\cline { 2 - 6 } & Kaligonj & Kapasia & Kalihati & Gopalpur & All Locations \\
\hline Required more labour & 100 & 100 & 53 & 100 & 88 \\
Application needs & 40 & 27 & - & 27 & 24 \\
carefulness & 73 & 40 & 53 & 27 & 48 \\
Required trained labour & 40 & 27 & - & 87 & 38 \\
Troublesome job & 20 & - & & 27 & 12 \\
USG not available & 20 & 27 & & 33 & 20 \\
Other problems & & & & & \\
\hline
\end{tabular}

Source: Field survey, 2008

\section{Conclusion and Policy Implication}

\section{Conclusion}

Results revealed that, comparatively low amount (3 6\%) of urea was needed in MV rice fields using USG instead of PU. Comparatively high labours were needed for the plots with USG application than the plots of PU application. Weeding cost was a little bit lower in USG using pots. Analysis also indicated that the sample farmers were able to achieve additional yield of $0.87 \mathrm{t} / \mathrm{ha}$ by using USG and this yield gain further resulted in additional benefit of Tk. 11506/ha. For the resource poor rice farms, this benefit is substantive. Farmers contact with the technology disseminators; training on rice production and the use of USG (instead of PU) were the important factors of increasing sample farmers' technical efficiency in crop management and productivity enhancement. Above 92 percent farmers agreed to the proposition that the use of USG would be of course economic for them since this practice required less urea in producing modern boro rice. According to the farmers' opinion, there were several constraints in using USG and out of those, requirement of more labour and nonavailability of USG in proper time were the important ones.

\section{Policy implication}

- Since use of USG was proved to be conducive in crop production, government efforts should be strengthened to promote field demonstrations and farmers' training on USG application in rice cultivation.

- Production and timely availability of USG at the farmers' level should be ensured in order to encourage farmers in using USG in crop production as per need. 


\section{References}

Aigner, D., C.A.K. Lovell and P. Schmidt. 1977. 'Formulation and Estimation and Stochastic Frontier Production function Models’. Journal of Econometrics 6: 21-27.

Alam, M. S. 2006. "Factors Affecting Yield Gap and Efficiency in Rice Production in some Selected Areas of Bangladesh”, Ph.D Thesis, Submitted to the faculty of Social Sciences, Department of Economics, Jahangirnagar University, Savar, Dhaka.

Bravo - Ureta. B.E. and R. E. Evenson. 1994. "Efficiency in Agricultural Prpduction: The case of Peasant Farmers in Eastern Paraguay. Agricultural Economics. 10: 27-37.

Battese, G.E. and T.J. Coelli. 1995. “A Model for Technical Inefficiency Effects in a Stochastic Frontier Production Function for Panel Data.” Empirical Econometrics 20: 325-332.

Battese, G.E. and G.S. Corra. 1977. "Estimation of a Frontier Model: With Application to the Pastoral Zone of Eastern Australia. Australian J. of Agric. Econ. 21: 167-179.

Bangladesh Bureau of Statistics (BBS). 2008. Statistical Year Book of Bangladesh, Statistics Division, Ministry of Planning, Government of the People's Republic of Bangladesh, Dhaka.

Bangladesh Rice Research Institute (BRRI). 2008. “Adhunik Dhaner Chash”, Bengali Version, Bangladesh Rice Research Institute, Gazipur- 1701.

Bangladesh Rice Research Institute (BRRI). 2007. Impact of LCC and USG on Rice Production in Some Selected Areas, Annual Research Review Report, Agricultural Economics Division, Bangladesh Rice Research Institute, Gazipur. 14-17 January.

Coelli, T.J. 1994. “A Guide to FRONTIER version 4.1, A Computer Programme for Stochastic Frontier Production and Cost Function Estimation. Department of Econometrics, University of New England, NSW 2351, Australia.

Coelli, T.J. 1995. Recent Developments in Frontier Modeling and Efficiency Measurement. Australian J. ofAgric. Econ. 39 (3): 2 19-245.

Farell, M. J. 1957. “The Measurement of Productive Efficiency,” Journal of Royal Stalistical Society, Series A (general), 120, Part III, 253-281. 